\title{
Coordination to Reduce Maternal and Infant Mortality in Tasikmalaya District
}

\author{
Jiwa Riwayanti ${ }^{1}$, Heru Nurasa ${ }^{2}$, Erlis Karnesih ${ }^{3}$ \\ Department of Public Administration \\ Faculty of Social and Political Science, Padjadjaran University \\ Email: riwayanti.jiwa@gmail.com ${ }^{1}$, heru.nurasa@unpad.ac.id², erlis.karnesih@unpad.ac.id ${ }^{3}$ \\ (Received: March 21-2020; revised: April 20-2020; published: June 31-2020)
}

\begin{abstract}
This research explains coordination to reduce maternal and infant mortality rates in Tasikmalaya District. The background of this study is the phenomenon of high maternal and infant mortality rates in West Java including in Tasikmalaya District. The method used in this research is descriptive with a qualitative approach carried out through interviews and observations of the parties involved in the expanding maternal and infant survival in Tasikmalaya District, reinforced by secondary data studies from the results of previous research, as well as data from related institutions. In order for the system in coordination to be effective it is necessary to improve in several aspects related to the system in coordination, in which there are three main dimensions in coordination, the dimensions of the mandate, systems and behaviors.
\end{abstract}

Keywords: Coordination; maternal; infant mortality

\section{INTRODUCTION}

Health development is an important part of a nation's development and is a basic service from the state to its people so that the highest degree of public health can be realized as an investment for the development of productive human resources (Phua et al., 2020; Shijagurumayum Acharya et al., 2015; Tonmoy et al., 2020). It is stated in the 1945 Constitution article $28 \mathrm{H}$ paragraph 1 that every person has the right to live in physical and spiritual prosperity, to have a place to live, to have a good and healthy environment, and to have health services.

Maternal Mortality Rate (MMR) and Infant Mortality Rate (IMR) are important indicators in measuring the public health quality of a country. Maternal Mortality Rate (MMR) and Infant Mortality Rate (IMR) in Indonesia are still relatively high (Brieba, 2018; Klugman et al., 2019; Nagarajan et al., 2015). Based on the 2012 Indonesian Demographic and Health Survey (IDHS), the Maternal Mortality Rate (MMR) (related to pregnancy, childbirth, and childbirth) reached 359 per 100,000 live births, while the infant mortality rate (IMR) reached 32 per 1000 live births (Ministry of Health Republic of Indonesia, 2015). 
288 Jurnal Ilmiah Ilmu Administrasi Publik: Jurnal Pemikiran dan Penelitian Administrasi Publik Volume 1o Number 1, January - June 2020. Page 287-296

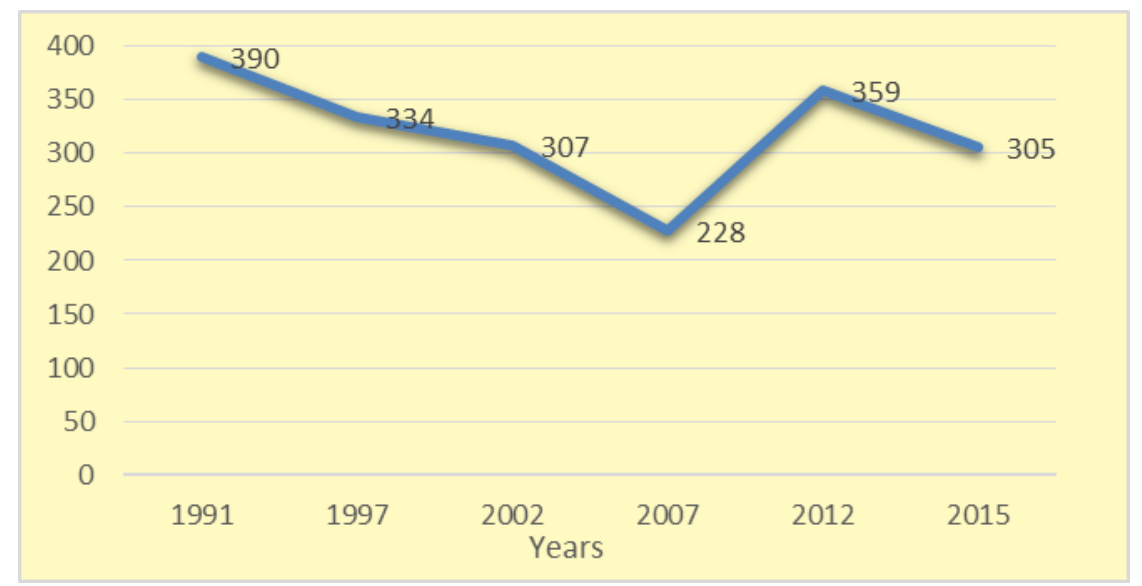

Figure 1

Indonesia's maternal mortality rate $1991-2015$

Source: Annual Report 2016, Family Health Directory, Department of Health

The maternal mortality rate has decreased in the period 1994-2012 but is still far from the expected target (MMR) of 70 per 100,000 births.

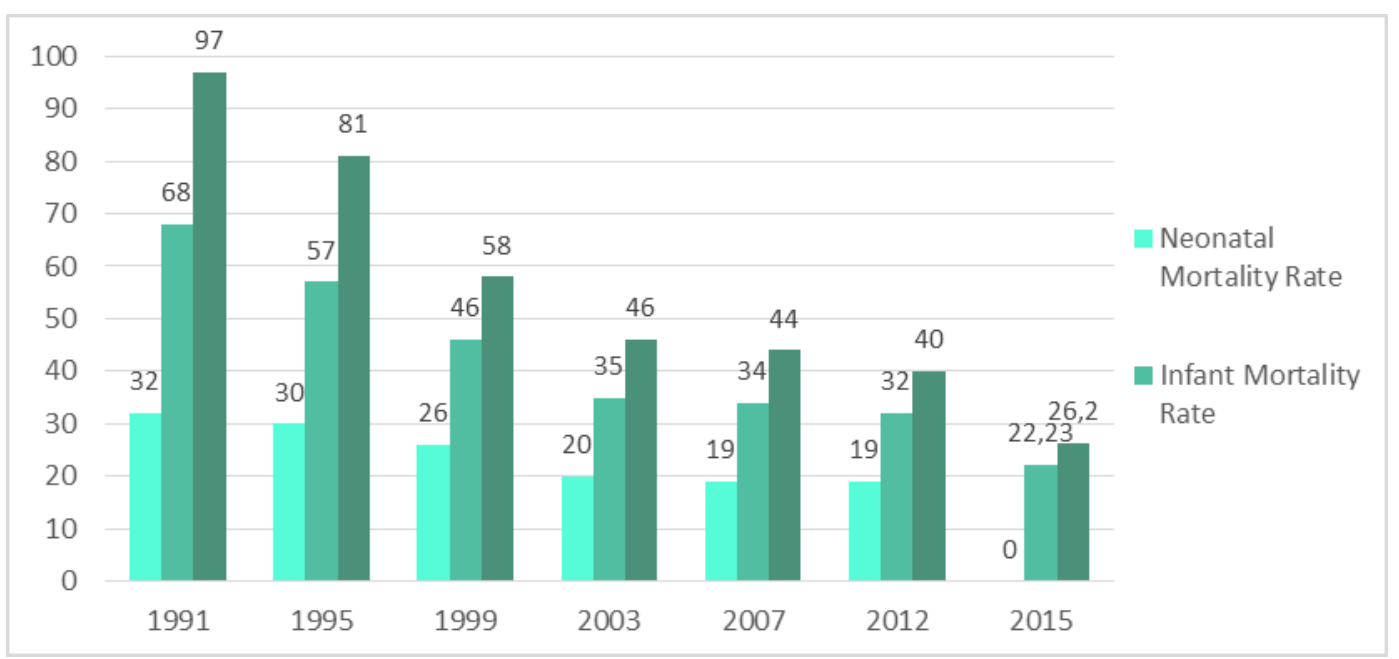

Figure 2

Infant Mortality Rate per 1,000 births in Indonesia 1991-2015

Source: Annual Report 2016, Family Health Directory, Department of Health

A decrease of IMR in 2015 is shown with the number 22.23 per 1,000 live births. Although the decline has not yet reached the target of the SDG's, which should have fewer than 12 infant deaths per 1,000 live births. Referring to current conditions, the potential to 
achieve the SDG target to reduce the MMR is still off track, meaning that it requires hard work and genuity to achieve it. Globally, SDG's (Suitainable Development Goals) target for IMR is less than 12 infant deaths per 1,000 live births and Maternal Mortality Rate (MMR) to 70 per 100,000 live births.

The number of Maternal Mortality Rates (MMR) and Infant Mortality Rates (IMR) recorded and reported by the West Java Provincial Health Office from year to year shows a decrease in numbers, but these figures are still relatively high (Head of West Java Provincial Health Office, 2015). The achievement of West Java is still far from SDG's target.

Table 1

MMR and IMR of West Java Province

\begin{tabular}{|l|c|c|c|}
\multicolumn{1}{|c}{ Indicator } & Unit & $\mathbf{2 0 1 3}$ & $\mathbf{2 0 1 4}$ \\
\hline Human Development Index & point & 73,40 & 74,28 \\
\hline a. Health Index & point & 72,60 & 74,01 \\
\hline a.1 Life Expentancy & Year & 68,80 & 69,02 \\
\hline a.2 Infant Mortality Rate & Per 1000 live birth & 30 & 30 \\
\hline a.3 Maternal Mortality Rate & Per 100.000 live birth & 359 & 359 \\
\hline
\end{tabular}

Source : Regional Profile of West Java Province 2015

The West Java Provincial Health Office notes that the maternal and neonatal mortality rate in a number of cities and districts in West Java are still quite high, according to the Head of the West Java Provincial Health Office the number of maternal deaths in 2015 reached 823 cases from the number of births reaching 951 thousand, meaning MMR reached 87 per 100,000 live births. (West Java Health Office, 2016). Similar conditions also occur in newborns which increased from 3,098 cases in 2014 to 3,369 cases in 2015. West Java still has a high contribution to maternal and infant mortality in Indonesia. (West Java Health Office, 2016)

The high number of maternal and infant deaths in West Java Province occurs in districts which are vulnerable to maternal and infant mortality. Tasikmalaya Regency ranks seventh in terms of maternal mortality, while infant mortality is in fourth position out of 27 cities / regencies in West Java. (Health Office of Tasikmalaya District, 2017).

Various efforts have been made by the government to reduce the MMR and IMR, ranging from placing midwives in villages, empowering families and communities, team of volunteer in newborn and children health, training classes for pregnant women, midwife and informal midwife partnerships, increasing maternal examinations pregnant through the revitalization of the integrated health service post or locally known as posyandu.

The program has not run optimally because many parties are needed to help the process of socialization to the community limited by the Office's ability to reach people in remote areas. 
290 Jurnal Ilmiah Ilmu Administrasi Publik: Jurnal Pemikiran dan Penelitian Administrasi Publik Volume 1o Number 1, January - June 2020. Page 287-296

Increase coverage of maternal and newborn rescue interventions

Improving the Quality of Maternal and Neonatal Emergency Services

Improving the Efficiency and Effectiveness of Referral Systems

\begin{tabular}{|c|c|}
\hline \begin{tabular}{l}
\multicolumn{1}{c}{ Quality Improvement } \\
- Strategic leadership and shared vision \\
- Clinical Performance Standards \\
- Behavioral intervention officers \\
- $\quad$ Health center (puskesmas) staff interns regularly at the \\
hospital \\
- AMP and Near Miss Audits \\
- SIPPP (SMS learning) \\
- Sigapku (SMS citizen feedback) \\
- Notice of Service
\end{tabular} & \begin{tabular}{l}
\multicolumn{1}{c}{ Strengthening References } \\
- Reference System Performance Standards \\
(APKR) \\
- PK among Health Facilities networks \\
- Sijari EMAS (referral exchange) \\
- AMP at the Regency level (pathway audit) \\
- Access to health services that are equitable \\
- Focus Groups (POKIA)
\end{tabular} \\
\hline \multicolumn{2}{|c|}{$\begin{array}{l}\text { - Community imvolvement } \\
\text { - Focus Groups- TWG multisector } \\
\text { - FMM-community members } \\
\text { - Community feedback (e.g. Sigapku, CRC) } \\
\text { - Advocacy with professionals, health offices, and other stakeholders }\end{array}$} \\
\hline
\end{tabular}

Figure 3

Efforts in decreasing MMR and IMR

Source: Tasikmalaya District Health Office

The Health Department acts as the leader in this sector, but coordination with other institution, both governmental and private, is necessary in implementing its policies and programs. In resolving maternal and infant mortality issues, support from organizations and related stakeholders is needed. Conceptually, coordination between organizations is needed because of limitations to solve their own problems. The fact is that geographically the Tasikmalaya Regency has a wide area with various rural locations.

The Office of Health should be the initiator in establishing coordination with related sectors, which have broad access to the public to conduct socialization. It is shown that efforts to decrease MMR and IMR have not yet achieved significant results, for this to make socialization of programs and coordinating between institutions more effective, Tasikmalaya published a Regent Decree No. 440 / Kep 128-Dinkes / 2016 regarding the establishment of a working group to save mothers and newborns consisting of: 1) Tasikmalaya District Health Office, 2) Regional Secretariat People's Welfare Section, 3) District Development Planning Agency, 4) Community Empowerment and Family Planning Agency, 5) District Hospital, 6) Ministry of Religion, 7) Indonesian Doctors Association, 8) Indonesian Midwives Association, and 9) Indonesian National Nurses Association. 


\section{METHOD}

The research method used in this study uses a qualitative approach with descriptive analysis methods. The subjects in this study are the Tasikmalaya District Health Office, the Tasikmalaya District General Hospital, the Tasikmalaya Regency Community Empowerment and Family Planning Agency, the Ministry of Religion of the Tasikmalaya Regency, the Indonesian Doctors Association of Tasikmalaya Branch, the Indonesian Midwives Association of Tasikmalaya Regency, the Indonesian National Nurses Association Tasikmalaya District, Tasikmalaya District Secretariat, and Tasikmalaya Regency Development Planning Agency. The type of data used in this study is in the form of text data in the form of documents and the results of interviews and observations (Creswell \& Creswell, 2017).

\section{RESULT AND DISCUSSION}

In a journal written by State Service Commission (SSC) entitled "Factor for Successful Coordination - A Frame for Help State Agencies Coordinate Effectively" (Commission, 2008) revealed there are three dimensions to achieving effective coordination, namely mandate, system and behavior.

\section{Mandate}

In Law Number 30 of 2014 concerning Government Administration, a mandate is defined as a devolution of authority from higher government bodies and / or officials to lower government agencies and or officials with responsibilities and accountability remaining with the mandate. The mandate aspect includes 3 (three) factors that support the commitment of the leader, the agreement of stakeholders, and clear and understood goals. The leader commitment factor can be seen from the role of the coordinator, the involvement of the leader in each activity, and the provision time to work together with the team. Then, the stakeholder agreement factor can be seen from how much sense of ownership of the stakeholders to work together. Finally, a clear and comprehensible goal factor can be analyzed by looking at how agencies can understand goals while working together (Baumgarten et al., 2020; Cho et al., 2019; Henderson \& Woodward, 2011; Krogh-Jespersen et al., 2020).

Activities undertaken to bring together stakeholders who play a role in reducing the MMR and IMR in the form of meetings attended by various related parties such as representatives of the Regional Secretariat, health offices, hospitals, professional organizations and others with the aim of building commitment from all parties to implement standardization of clinical governance on maternal and infant health services and their prevention both at the hospital level, the Health Service and other regional apparatus. This activity has been carried out in the presence of relevant parties in the Tasikmalaya Regency with a commitment to implement the programs.

The establishment of a Working Group (Pokja) to save mothers and babies in Tasikmalaya Regency is regulated in the Decree of the Regent No. 440 / Kep 128-Dinkes / 


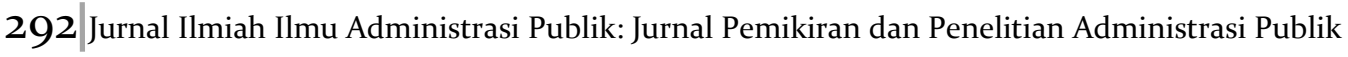

Volume io Number 1, January - June 2020. Page 287-296

2016. The referral agreement aims to equalize perception, understanding related to the referral process and cooperation among fellow health service institutions so that the referral services can be of high quality so that efforts to save mothers and babies can be successful. The agreement should be stated in a memorandum of understanding (MOU) so that it becomes a joint commitment between various institutions in supporting efforts to save mothers and babies. A referral MOU was signed between the Tasikmalaya District Health Office representing the Public Health Center (Puskesmas) and the Tasikmalaya District Hospital as a secondary service for referral to maternal and newborn cases.

Transparency and accountability are realized by empowering community participation in the rescue program for mothers and newborns (Wildana \& Awaru, 2018). For this reason, it requires the involvement of many parties, not only the government but also the community. Optimizing the transparency and accountability of health services related to saving mothers and newborns is expected to accelerate the decline in MMR and IMR, which in turn can improve the health status of the Indonesian people. The activities carried out within the framework of the concept of the Mother and Newborn Rescue Program to build transparency and accountability of services consist of:

- Establishment of a Working Group (Pokja) to Rescue Mothers and Newborns

- Involving the active role of the community in the rescue program for mothers and newborns in the form of: Civil Society Forum, the existence of a Mother and Child Health Motivator, active role in encouraging the management of Feedback, both in the form of direct feedback management in the form of complaints desk, suggestion box, SMS, etc., and in the form of managing indirect feedback initiated by service providers or together with the community, for example through the Citizen Report Card (CRC), Citizen Scored Card (CSC) or Community Assessment Card (KPM), or through Joint Monitoring

- Advocacy for stakeholders, government, professional organizations and various institutions related to saving mothers and newborns.

From the research conducted by the author, it can be seen that aspects of the mandate have been formed with the issuance of the agreement, and each Regional Organization involved is ready to support to reduce the Maternal and Infant Mortality in Tasikmalaya Regency.

\section{System}

In organizations there is a change from input to output, requiring many interconnected processes of existing structural functions. The process includes coordination between units within the organization both structural and functional to achieve output or shared goals (Akib et al., 2016; Ismail et al., 2016). Coordination in the dimensions of the system according to the State Service Commission (SSC) consists of 3 (three) factors, namely the framework and responsibilities, appropriate and sufficient resources, as well as the process of measuring performance and basic guidelines. The framework and responsibilities can be seen from how the Standard Operating Procedure (SOP) is used and the mechanism of responsibility contained in the working group. Then the sufficient and appropriate resource factor is seen from the financial system in implementing programs to reduce the MMR and IMR. Finally, 
the process factors measuring performance from basic guidelines can be analyzed by looking at how agencies progress, understanding the contents of the regional action plan and disseminating the information.

Based on the findings in the field, coordination between each Regional Apparatus Organization related to the program of reducing maternal and infant mortality in Tasikmalya Regency is not routinely carried out. Each regional apparatus organization involved is operating according to its tasks and functions, but there is no joint evaluation or routine meetings as a working group to reduce maternal and infant mortality rates. Human resources as the executor of the rescue program for mothers and newborns in Tasikmalaya Regency not only involve people from the government, especially Tasikmalaya District Health Office, but also involve other related DPOs. It also involves non-governmental actors, namely professional health organizations such as the Indonesian Doctors Association, the Indonesian Midwives Association and the Indonesian National Nurses Association. In the District Head's Decree, it is stated that regular meetings are held every three months but in practice these routine meetings have not yet been carried out, due to various constraints such as time and budget.

Appropriate and sufficient human resources, budget, and time are very important for the continuation of coordination activities. Budget is an inseparable thing in a good policy in the planning and implementation process.

\section{Behaviour}

Behavioral dimensions in coordination to reduce maternal and infant mortality rates is related to the accuracy and ability of the representatives and team leadership (Niswaty et al., 2019; Wader et al., 2020). This dimension is also related to organizational behavior and culture, which can be seen from the support of each organization that is seen in the activities of reducing maternal and infant mortality in Tasikmalaya Regency.

Relating to aspects of organizational culture that supports coordination in reducing maternal and infant mortality rates in Tasikmalaya Regency, the authors consider that these aspects are sufficiently supportive. This can be seen from the activities carried out by several institutions, so that this form of support will facilitate the implementation of programs.

The coordination team consists of several fields, each sector despite having its own duties and functions, but each field cannot be completely independent from other fields because it cannot function properly without the assistance of other fields, and each field is obliged to support the implementation of others' functions for smooth and effective implementation of duties to achieve the goal. For this reason, mutual respect is needed between each field. Looking at the important tasks and authority of each field will create mutual understanding in the coordination team. With mutual respect and understanding, a growing enthusiasm will be created to help each other in this coordination team.

The involvement of several organizational units in reducing maternal and infant mortality provides opportunities for the formation of gaps due to different duties and authorities and different work environments. However this should not happen and should be avoided in the realization of good coordination. The gap usually occurs because of the similarity of views between some units and different from other units. Effective coordination 
294 Jurnal Ilmiah Ilmu Administrasi Publik: Jurnal Pemikiran dan Penelitian Administrasi Publik Volume 1o Number 1, January - June 2020. Page 287-296

allows a gap where all the differences can be put together and look for similarities that give birth to cohesiveness in coordination.

\section{CONCLUSION}

Based on the results of the research described by the author in the previous chapter, it can be concluded that the government program has succeeded in reducing maternal and newborn mortality rates in Tasikmalaya District but this reduction target has not met the expected target of the SDG's target. This is because there are still some obstacles, coordination is not yet fully in line with the mandate dimension, system dimension, and behavioral dimension, and organizational culture that supports coordination in reducing maternal and infant mortality rates in Tasikmalaya District.

Some things that have been sufficiently fulfilled from the three dimensions, namely those related to leadership commitment, stakeholder involvement, clear and mutually agreed upon goals. However, other aspects in the system dimensions such as the framework and accountability, performance measurement, limited human resources and program evaluations have not been running routinely, and the adequacy and availability of resources are still not optimal.

\section{REFERENCES}

Akib, H., Guntur, M., \& Salam, R. (2016). Civitas Academic Perception of "Blissful Services" for Recipient Postgraduate Program State University of Makassar, Indonesia. International Conference on Public Organization VI (ICONPO VI), 340-350.

Baumgarten, M., Brødsgaard, A., Bunkenborg, G., Foss, N. B., \& Nørholm, V. (2020). Nurse and Physician Perceptions of Working With Goal-Directed Therapy in the Perioperative Period. Journal of PeriAnesthesia Nursing, 35(2), 198-205. https://doi.org/https://doi.org/10.1016/j.jopan.2019.09.005

Brieba, D. (2018). State Capacity and Health Outcomes: Comparing Argentina's and Chile's Reduction of Infant and Maternal Mortality, 1960-2013. World Development, 101, 3753. https://doi.org/https://doi.org/10.1016/j.worlddev.2017.08.011

Cho, S., Kim, M. A., \& Kwon, S. Il. (2019). Using the photovoice method to understand experiences of people with physical disabilities working in social enterprises. Disability and Health Journal, 12(4), 685-693. https://doi.org/https://doi.org/10.1016/j.dhjo.2019.03.011

Creswell, J. W., \& Creswell, J. D. (2017). Research design: Qualitative, quantitative, and mixed methods approaches. Sage publications.

Henderson, A. M. E., \& Woodward, A. L. (2011). "Let's work together": What do infants understand about collaborative goals? Cognition, 121(1), 12-21. 
https://doi.org/https://doi.org/10.1016/j.cognition.2011.05.008

Ismail, A., Sulur, A. H., Akib, H., \& Salam, R. (2016). Snapshot of Society Social-Economic Welfare based on Human Development Index in Polewali Mandar Regency, Indonesia. International Conference on Public Organization VI (ICONPO VI), 847-858.

Klugman, J., Li, L., Barker, K. M., Parsons, J., \& Dale, K. (2019). How are the domains of women's inclusion, justice, and security associated with maternal and infant mortality across countries? Insights from the Women, Peace, and Security Index. SSM $\begin{array}{llll}\text { Population Health, } & 100486 .\end{array}$ https://doi.org/https://doi.org/10.1016/j.ssmph.2019.100486

Krogh-Jespersen, S., Henderson, A. M. E., \& Woodward, A. L. (2020). Let's get it together: Infants generate visual predictions based on collaborative goals. Infant Behavior and Development, 59, 101446. https://doi.org/https://doi.org/10.1016/j.infbeh.2020.101446

Nagarajan, S., Paul, V. K., Yadav, N., \& Gupta, S. (2015). The National Rural Health Mission in India: its impact on maternal, neonatal, and infant mortality. Seminars in Fetal and Neonatal Medicine, 20(5), 315-320. https://doi.org/https://doi.org/10.1016/j.siny.2015.06.003

Niswaty, R., Juniati, F., Darwis, M., Salam, R., \& Arhas, S. H. (2019). The Effectiveness of Leadership Functions Implementation in The Makassar Departement of Manpower. JPBM (Jurnal Pendidikan Bisnis Dan Manajemen), 5(1), 1-10.

Phua, D. Y., Kee, M. Z. L., \& Meaney, M. J. (2020). Positive Maternal Mental Health, Parenting, and Child Development. Biological Psychiatry, 87(4), 328-337. https://doi.org/https://doi.org/10.1016/j.biopsych.2019.09.028

Shijagurumayum Acharya, R., Wanvik, A. K., \& Stensdotter, A. K. (2015). Community placement for students is an important resource for the development of the primary level health sector in Nepal. Physiotherapy, 101, e1385-e1386. https://doi.org/https://doi.org/10.1016/j.physio.2015.03.1330

Tonmoy, F. N., Cooke, S. M., Armstrong, F., \& Rissik, D. (2020). From science to policy: Development of a climate change adaptation plan for the health and wellbeing sector in Queensland, Australia. Environmental Science \& Policy, 108, 1-13. https://doi.org/https://doi.org/10.1016/j.envsci.2020.03.005

Wader, N., Darwis, M., Salam, R., \& Baharuddin, A. (2020). Application of the Transformational Leadership Style at the BKKBN office in South Sulawesi Province. PINISI Discretion Review, 1(1), 7-12.

Wildana, A., \& Awaru, A. O. T. (2018). Perilaku Akademik Aktivis (Studi Kasus Pada Mahasiswa Fis UNM Yang Aktif di Organisasi Daerah). JURNAL SOSIALISASI, 1-6. 
296|Jurnal Ilmiah Ilmu Administrasi Publik: Jurnal Pemikiran dan Penelitian Administrasi Publik Volume 1o Number 1, January - June 2020. Page 287-296 